\title{
APPLICATION OF A SYSTEMS APPROACH TO STUDYING GLOBAL SOCIO-ECONOMIC INEQUALITY
}

\section{Abstract}

Ideas drawn from broadly-defined systems thinking, including complex systems studies, have already been used to describe and explain social and economic inequality at various levels of the societal hierarchy, beginning with individuals and ending on the global scale. Bearing in mind the studies on economic and social inequality, the following research question can be asked: What are the universal, systemic characteristics of socio-economic inequality on the global scale? How could a systems approach, including complex systems studies, be helpful in studying socio-economic inequality on the global scale? As a point of departure in the literature survey, two conjectures are formulated and discussed. First, socio-economic inequality constitutes an inherent part of developed societies on the global scale and affects regions, countries, social groups, and individuals. Second, a systems approach, and complex systems studies in particular, can be helpful in analyses of socio-economic inequality

Czesław Mesjasz, Cracow University of Economics, Management Process Department, Rakowicka 27, 31-510 Kraków, Poland, e-mail: mesjaszc@uek.krakow.pl, ORCID: https://orcid.org/ 0000-0003-0893-5823.

Lidia Mesjasz, Cracow University of Economics, Department of International Economics, Rakowicka 27, 31-510 Kraków, Poland, e-mail: mesjaszl@uek.krakow.pl, ORCID: https://orcid.org/ 0000-0001-6365-0834.

This publication presents the results of a research project financed from a subsidy for the maintenance of research potential granted to the Management Process Department, Faculty of Management, Cracow University of Economics (Czesław Mesjasz), Project: 040/ WZ-KPZ/01/2019/S/904.

This is an open access article distributed under the terms of the Creative Commons Attribution-NonCommercial-NoDerivatives 4.0 License (CC BY-NC-ND 4.0); https://creativecommons.org/ licenses/by-nc-nd/4.0/. 
by helping to identify causal relations. This concerns, in particular, the theory of hierarchical systems and the Power Law.

Keywords: complex systems, inequality, systems approach, Power Law, scale-free networks.

JEL Classification: C54, D31, D63, F60, I30.

\section{Introduction}

Several works on social and economic inequality were published in the late $20^{\text {th }}$ and early $21^{\text {st }}$ centuries (Sen 1995, Milanovic 2005, Stiglitz 2012). An important contribution to the discussion was made by Piketty (Piketty 2014, Piketty \& Saez 2014). These publications were supplemented by other works (Stiglitz 2015, Milanovic 2016). Theoretical considerations have been accompanied by more or less "shocking" reports and numerous empirical research papers illustrating the dramatic discrepancies in the distribution of income and wealth on the global scale.

Ideas drawn from broadly-defined systems thinking, including complex systems studies, have already been used directly and indirectly to describe and explain social and economic inequality (Barabási 2003, Yakovenko \& Rosser 2009, Chatterjee et al. 2015, Krauss 2015). Bearing in mind the above-mentioned works on economic and social inequality, the following research question can be asked: What are the universal, systemic characteristics of socio-economic inequality on the global scale?

As a point of departure in the literature survey, two conjectures are formulated. First, socio-economic inequality constitutes an inherent part of developed societies on the global scale and affects regions, countries, social groups, and individuals. Second, a systems approach, and complex systems studies in particular, can be helpful in analyses of socio-economic inequality by helping to identify the causal relations determined by hierarchical structures and the consequences of the Power Law. The main method applied in this paper is a literature survey that includes both theoretical considerations and - for reasons of space - a survey of selected information sources, especially reports published by various public and private international institutions.

\section{Interpretations of Socio-economic Inequality on the Global Scale}

When discussing inequalities in society, it is important to make two distinctions. The first is the difference between the unequal distribution of desirable life outcomes, such as health, happiness, educational success and 
material possessions, and the unequal distribution of opportunities, such as access to power and life chances that facilitate the achievement of desirable outcomes. The second is the distinction between the unequal distribution of opportunities and outcomes among individuals and between groups (Carter \& Reardon 2014, p. 3). On the global scale, inequality between countries and regions also has to be taken into account.

Two interpretations of inequality are distinguished - social and economic. Social inequality exists when resources and rights in a society are distributed unevenly, typically through norms of allocation that result from differences in the individual social roles of socially defined types of individuals. They are differentiated according to power, religion, kinship, prestige, race, ethnicity, gender, age, and class. Social rights include the labour market, source of income, health care, freedom of speech, education, political representation, and participation. Socio-economic inequality can lead to conflicts, wars, crises, oppression, criminal activity, political unrest and instability, and indirectly affects economic growth. Specific links exist between three measures of economic inequality ("A Three-headed Hydra" 2014). Income inequality is the most commonly cited measure, primarily because the data on it is the most comprehensive. However, for the purpose of measuring how inequality affects a community, it is also probably the least valuable measure. Consumption inequality, though more difficult to measure, is a better representation of social welfare because people's living standards depend on the number of goods and services they consume. Wealth is also an important metric since it can be inherited, unlike income. Milanovic (2005, pp. 7-11) has proposed three concepts of global inequality. First, unweighted international inequality - the inequality in per capita incomes among the countries in the world. Second, population-weighted international inequality or between-country inequality, which measures inequality among persons by assigning everybody the per capita income of his place of residence. It thus ignores any within-country inequality. Third, global interpersonal inequality, which captures the inequality of individual incomes.

Economic inequality is not necessarily associated with the allocation of broadly defined resources. According to A. Sen, equalizing income should not be the goal, because not all people convert income into well-being and freedom in the same way. What is more, this relationship seems highly dependent on "contingent circumstances, both personal and social" (Sen 1999, p. 70) that include the individual's age, gender, family background, and disability. It also depends on climatic conditions, societal conditions 
(health care, education systems, the prevalence of crime, community relationships), customs and conventions, and other factors. Hence, what should be equalized is not the means of living, but the actual opportunities of living that give people the freedom to pursue a life of their own choosing.

\section{The Idea of Complex Systems}

In his search to explain the meaning of complexity, Lloyd (2001) identified 45 interpretations. Studies of complexity are rooted in cybernetics and systems thinking1: Weaver (1948) - disorganized complexity and organized complexity, Simon (1962) - The Architecture of Complexity, and Ashby (1963) - the Law of Requisite Variety. A picture of the intricacy of the field of complexity science can be found in the scheme proposed by Castellani (2018). In other writings numerous definitions of complexity have been formulated and scrutinized - Prigogine and Stengers (1984), Waldrop (1992), Kauffman (1995), Holland (1995), Bar-Yam (1997), Biggiero (2001), Andriani and McKelvey (2009), and Mesjasz (2010).

An unequivocal distinction of complex systems from "classical" systems is not possible. In the works defining "first-order cybernetics" (Wiener 1961, Ashby 1963) and in the fundamental book on systems thinking (Bertalanffy 1968 ) in which the role of observer was not considered, complexity was treated as one of the important systemic features. In those works, the first systemic/cybernetic characteristics of systems were enumerated: system, element, relation, subsystem, environment, input, output, feedback, black box, equilibrium, stability, synergy, and turbulence.

In a preliminary interpretation, the complexity of systems derives from the number of elements and the number of their interactions. Furthermore, it can be also characterized by a multitude of such traits as adaptability, adaptation, attractor, autopoiesis, chaos, bifurcations, butterfly effect, closed system, coevolution, complex adaptive systems, dynamical systems, edge of chaos, emerging properties, far-from-equilibrium states, fitness landscape, fractals, nonlinearity, open system, path dependence, power law, reflexivity, scale-free networks, self-organization, self-organized criticality, self-reflexivity, synergy, synergetics, and turbulence.

Two problems of complex systems studies demand further clarification. First, in the mathematical models applied in complexity studies, intricate

${ }^{1}$ Relations between those two areas of knowledge require further elucidation. Due to the many interpretations of their relations, in this paper systems thinking is regarded as the most general category. 
behaviour results from simple patterns. This means that in order to understand complex dynamics, identification of simple rules could be sufficient, e.g. the Power Law reflected also in the Pareto Law (Andriani $\&$ McKelvey 2009). Second, complex systems exhibit non-linear behaviour that is referred to as positive feedback where internal or external changes to a system produce amplifying effects. Non-linear systems can generate a specific temporal behaviour which is called chaos. During unstable periods, such as chaos, non-linear systems are susceptible to shocks (sometimes very small). This phenomenon, called "sensitivity to initial conditions" and popularized as Lorenz's "butterfly effect", exemplifies cases where a small change may generate a disproportionate change (Gleick 1987). Ideas that originated in systems thinking and complexity studies are used in social sciences as models, analogies, and metaphors. According to this distinction, the term "model" is narrowed only for mathematical structures. Therefore, the role of analogies and metaphors taken from complexity studies must be taken into account (Lakoff \& Johnson 1995). While the above ideas refer to several classes of mathematical models, a qualitative approach to the complexity of social systems has been developed by N. Luhmann (1995, 1997) and P. Cilliers (1998).

\section{Systemic Internal Hierarchies and Inequality}

A hierarchical structure occurs in all interpretations of systems and their complexity. In addition, the increasing complexity of social systems is reflected in various types of internal hierarchy and inequality. According to studies of society, hierarchical structures emerged as a consequence of the increasing complexity of decision-making processes within the primitive tribes, since complex decisions could not be made by consensus ${ }^{2}$. Various types of hierarchies in social systems can emerge. A hierarchy of power and of resource allocation may be also imposed. When discussing processes of differentiation in social systems, their "holonic" character has to be taken into consideration. Therefore, three terms have to be scrutinized: hierarchy, heterarchy, and holarchy.

Although numerous works on systems hierarchy have been written, the universal ideas introduced by Simon $(1962,1995)$ and Bertalanffy (1968) remain relevant. In the simplest sense, hierarchy is a relation of

${ }^{2}$ The links between the development of societies and the evolution of social hierarchies have been studied by Turchin and Gavrilets (2009). 
subordination. In social systems the following types of the hierarchy may be distinguished:

1) Power hierarchy.

2) Functional hierarchy.

3) Nested, a recursive (fractal) hierarchy which can be illustrated with the Russian doll ("matrioshka"), where the hierarchical elements are self-similar.

4) Containment hierarchy, which is a nested hierarchy in which the subsets must be different.

5) Subsumptive containment hierarchy, which is a classification of object classes.

6) Compositional containment hierarchy, which is an ordering of the parts that make up a system - the system is "composed" of these parts. Most engineered structures, whether natural or artificial, can be broken down in this manner. What is also important in this type of hierarchy is that new properties are emerging, i.e. it is not possible to predict the behaviour of a higher-level system by observing systems at a lower level of the hierarchy.

Another type of internal ordering of systems is heterarchy, which can be defined as a synthesis of any type of hierarchical ordering with elements of the same rank. Similarly to hierarchical structures, heterarchy may have a recursive character. The last type of ordering needed to better understand the internal differentiation in society is holarchy. The concepts of holon and holarchy were introduced by Koestler (1967). Holon is an element of the entity that is similar to the entity (sub-entity). In other words, holons treated as elements of systems include information about the entire system. An analogy with social systems is obvious. In Complex Adaptive Systems (CAS), elements have only simple algorithms of behaviour, e.g. bees in the beehive or simple models of human behaviour ${ }^{3}$. If such elements are given cognitive capabilities and memories they become to be similar to social systems ${ }^{4}$.

The hierarchical structure of complex systems was studied in detail by Simon $(1962,1995)$. He distinguished between subjective hierarchy deriving from cognitive limitations and physical hierarchy, and concluded that hierarchical structure is an objective feature of any system (Simon 1962). Each level of hierarchy has its specific characteristics. One of them, which may seem important from the point of view of socio-economic inequality and stratification, is termed near decomposability by Simon (1995).

\footnotetext{
${ }^{3}$ A description of complex adaptive systems (CAS) and their applications can be found in Holland (1985), Waldrop (1992), and Shan \& Yang (2008).

${ }^{4}$ Holarchy can be also viewed as a fractal structure (Warnecke 1993).
} 
According to Simon, all systems - physical, social, biological, and artificial - share the property of having a near decomposable architecture. They are organized into hierarchical layers of parts, parts of parts, parts of parts of parts and so on, in such a way that interactions among elements belonging to the same parts are much more than interactions among elements belonging to different parts. "Intense" interaction is understood to mean that the behaviour of one component depends more closely on the behaviour of other components belonging to the same part than on components belonging to other parts (i.e. the cross-derivatives are larger within a part). This kind of architecture can be found in all social systems, including companies, where the division of labour, divisionalization, and hierarchical decomposition of tasks are all elements which define a near decomposable system: individuals within a hierarchical subunit have closer, more widespread, more intense, and more frequent interactions than individuals belonging to different subunits. This property shows that elements at the same level of the hierarchy are in a natural manner connected by stronger ties. This allows systemic hierarchy models to be used in the study of the theory of social and economic inequality.

\section{Complexity and Systemic Inequality in Society: Examples}

\subsection{Assumptions behind the Selection of Examples}

Two examples presented below illustrate the application of complex systems studies when analyzing various aspects of socio-economic inequality. In sub-chapter 4.2 the applications of the Power Law (Pareto distribution/ Lorenz curve/Zipf's Law - a special case) in modelling socio-economic inequality are presented, including scale-free networks. Sub-chapter 4.3 includes the results of measurement of inequality on the global scale which indirectly illustrate changes in modern society where economic activities are decoupled from financial activities.

\subsection{Power Law and Socio-economic Inequality}

Empirical observations concerning wealth allocation were advanced by Pareto in a more universal framework of the 80-20 rule already in the early $20^{\text {th }}$ century. It is sufficient to recall here that this involved not only methods of measurement and interpretation, as for example, the Gini coefficient, but also models allowing for the identification of causal links and for prediction. The rising interest in socio-economic inequality in the 1970s and 1980s 
coincided with the development of complexity studies, in which the Power Law is one of the main ideas.

Cumulative distributions with a power-law form are sometimes said to follow Zipf's Law or the Pareto distribution, after two early researchers who championed their study. Since Power Law cumulative distributions imply a Power Law form for $p(x)$, "Zipf's Law" and the "Pareto distribution" are effectively synonymous with the "Power Law distribution" (Zipf's Law and the Pareto distribution differ from one another in the way the cumulative distribution is plotted - Zipf made his plots with $x$ on the horizontal axis and $p(x)$ on the vertical one; Pareto did it the other way around). This causes much confusion in the literature, but the data depicted in the plots are of course identical (Newman 2006, p. 4). A very general interpretation of the Power Law is presented in Figure 1.

Bell Curve

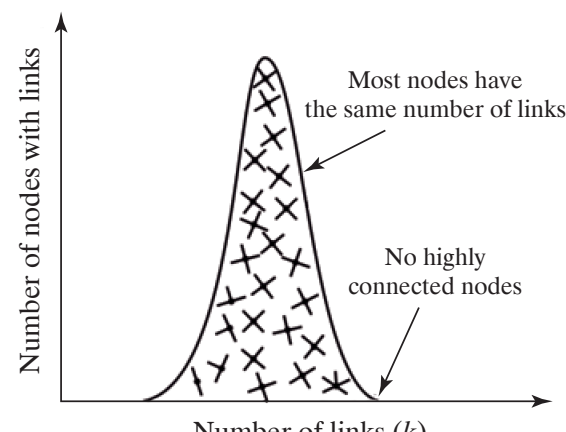

Number of links $(k)$
Power Law Distribution

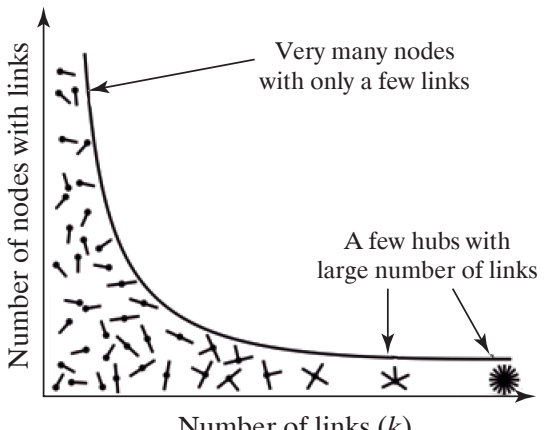

Number of links $(k)$

Fig. 1. Comparison of the Gauss Distribution with the Power Law with Reference to Scale-free Networks

Source: Barabási (2003, p. 71).

The Power Law has multiple applications in modelling various phenomena in physics, biology, society, linguistics, urban studies, etc. It has become both a fundamental model of socio-economic inequality as well as a source of metaphors and analogies. The most significant aspect of the Power Law is that to some extent it reflects the situation in society in which privileged groups receive the majority of resources. The Power Law distribution is not ubiquitous in any relation of socio-economic inequality. Empirical studies have found Power Law behaviour in the distribution of income in Australia, Germany, India, Italy, Japan, the UK, and the USA. 
Another group of studies has discovered a Power Law structure of the upper tail of modern wealth distributions in China, France, India, Sweden, the UK, and the USA (Brzeziński 2013, p. 2). However, as was exposed by this author, detecting the Power Law distribution in the empirical data on inequality is not simple. Therefore, a complete empirical analysis would require conducting a statistical comparison of the Power Law model with some other distributions. Brzeziński (2013) has found that top wealth values follow Power Law behaviour in only $35 \%$ of the analyzed cases. The recently published study by Broido and Clauset (2018) confirms that scale-free networks are not too frequent either in nature or in social systems, and new studies are required.

Applications of the Power Law distribution in the study of inequality have become an important part of econophysics research (Yakovenko \& Rosser 2009) $)^{5}$. In addition to the use of the above models, the following models of wealth inequality are applied: chemical kinetics-motivated Lotka-Volterra models, polymer physics-inspired models and, most importantly, models inspired by the kinetic theory of gases (Chatterjee et al. 2015). Those applications have some merit, but they should not be seen as more "scientific" proof of the theses concerning the inequality of wealth distribution.

One of the most influential ideas of complex research applied in studies of socio-economic inequality is the scale-free networks elaborated by Barabási and Albert (Barabási \& Albert 1999, Barabási 2003). After finding that various networks, including some social and biological networks, had heavy-tailed degree distributions, Barabási and his collaborators coined the term "scale-free network" to describe the class of networks that exhibit a Power Law degree distribution, which they presumed to describe all real-world networks of interest. They have been extensively applied in studying the topology of the internet, social networks, and in all cases where relations between actors may have a network-like character. One of characteristics of scale-free networks is "preferential attachment". This means that those elements of the network are gaining even more links since they have already gained more links. In reference to socio-economic inequality, this may mean that a kind of "eigendynamik" of inequality stems from the fact that those who are more privileged more frequently enter into relations among themselves. Buchanan (2002) calls the random networks "egalitarian" and

${ }^{5}$ Econophysics is a new branch of physics which focuses on studying economic and social phenomena with ideas and methods drawn from physics. The most important concepts of econophysics are models deriving from "complexity theory" and "chaos theory" (Mesjasz 2010). 
the scale-free networks "aristocratic" (2002, p. 119). Here appears the "rich get richer" phenomenon that is supposed to be valid for all networks in nature, including the economy and the wider society (Barabási 2003, pp. 79-92; Buchanan 2002, pp. 106-120, 192-195). The positions of actors in scale-free networks are not equal and hubs (most often selected nodes) are the "spiders in the net" (van Dijk 2005, pp. 150, 151).

\subsection{Inequality on the Global Scale}

In spite of doubts concerning the relevance of the Power Law to present-day inequality, it may be stated that there exists a striking coincidence between this law and global disparity in wealth and income disparity. In addition to showing inequality on the global scale, studies based on the third definition proposed by Milanovic (2005, pp. 7-11) also indirectly illustrate the Power Law-like character of inequality in modern society. Those studies are widely described in literature (Milanovic 2005, 2016, Lakner \& Milanovic 2013, 20156, Alvaredo et al. 2017, World Inequality Report 2018). A study of the dynamics of global income interpersonal inequality in the years 1988-2008 was conducted by Lakner and Milanovic (2013, 2015) - Figure 2.

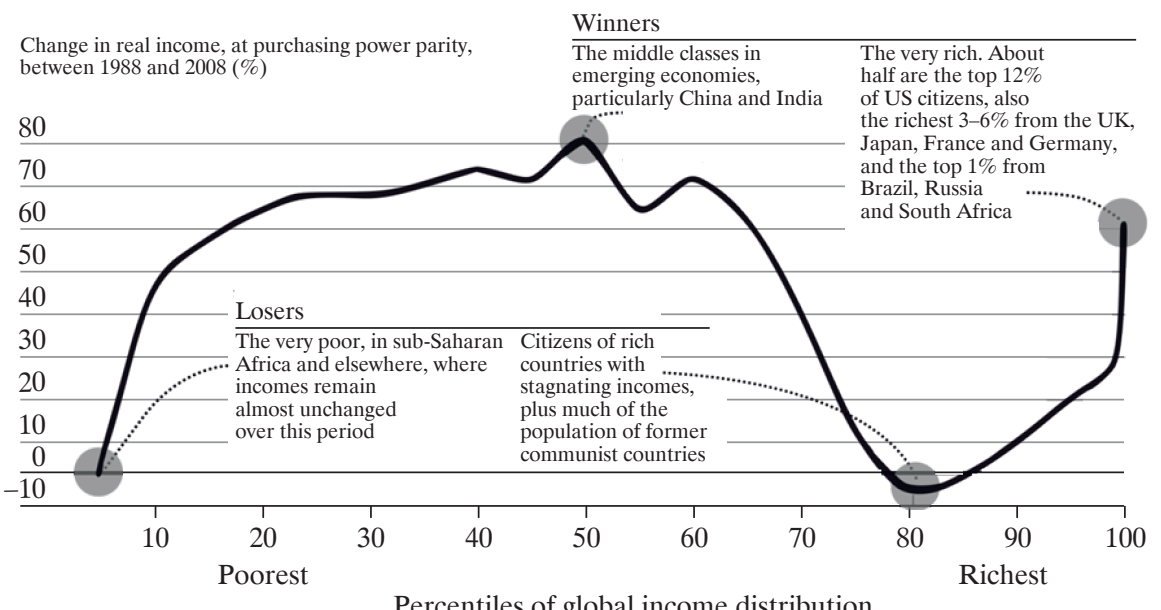

Fig. 2. Global Income Growth and Participation in That Growth, 1988-2008 (Incidence Curve)

Source: Lakner \& Milanovic (2013, 2015), van der Bosch (2017).

\footnotetext{
${ }^{6}$ In the paper, two texts by Lakner and Milanovic are referred to $(2013,2015)$. They concern the
} same topic but differ in content and size. 
The authors and their supporting team performed very advanced data gathering, processing, and analysis aimed at investigating changes in inequality worldwide during the 1988-2008 period by assessing the distribution of global growth of individual income across various social groups. Their first finding was that inequality in the global income distribution, as measured by the Gini index, did not change very much over this period and remained at the level of $70 \%$, which is a higher value than that obtained in other studies. More advanced data searches for household income and deeper research allowed new phenomena in the global income distribution to be discovered.

The results of their research were presented on a graph in which the $X$ axis depicts the percentiles of the global income distribution among the deciles of the population. The $Y$ axis reflects the cumulative growth rate in real income measured by purchasing power parity in the 1988-2008 period. Due to its shape, the graph has become popularly known as the "Elephant Curve" ("Elephant Chart"). The graph has received multiple interpretations, which expose such phenomena as diminishing income inequality in the world but only slightly rising standards of living in poor countries (Freund 2016).

The most important result of this study is the disproportion in income distribution between the broadly defined "middle class" and the richest group in the world (decile 90). An increase in the share of income growth by the middle class was observed mainly in China and India (deciles 40-60). On the other hand, the middle class in rich countries, such as the US and Germany as well as post-Soviet economies, experienced sluggish growth or no growth at all. The tip of the elephant's trunk, on the far right (decile 90), shows that the world's super-rich mostly from developed countries such as the USA, UK, Japan, and Germany, and with a smaller proportion the richest individuals from developing countries such as Brazil, Russia, and South Africa, have the largest share in the growth of income in that period.

A similar study covering the 1988-2016 period was performed by F. Alvaredo, L. Chancel, T. Piketty, E. Saez, and G. Zucman (World Inequality Report 2018). Studies of the links between the information society and inequality suggest taking a look at the right corner of the graph in order to assess who are the richest groups receiving the highest proportion of the global income's growth. This phenomenon is analyzed in the report and mirrored in another "Elephant Curve". The explosion of top incomes on the far right of the graph now dwarfs the whole picture and it looks more 
like a brontosaurus, or alternatively "Nessie", Disney's version of the Loch Ness monster, than an elephant (Sandefur 2018), Figure 3.

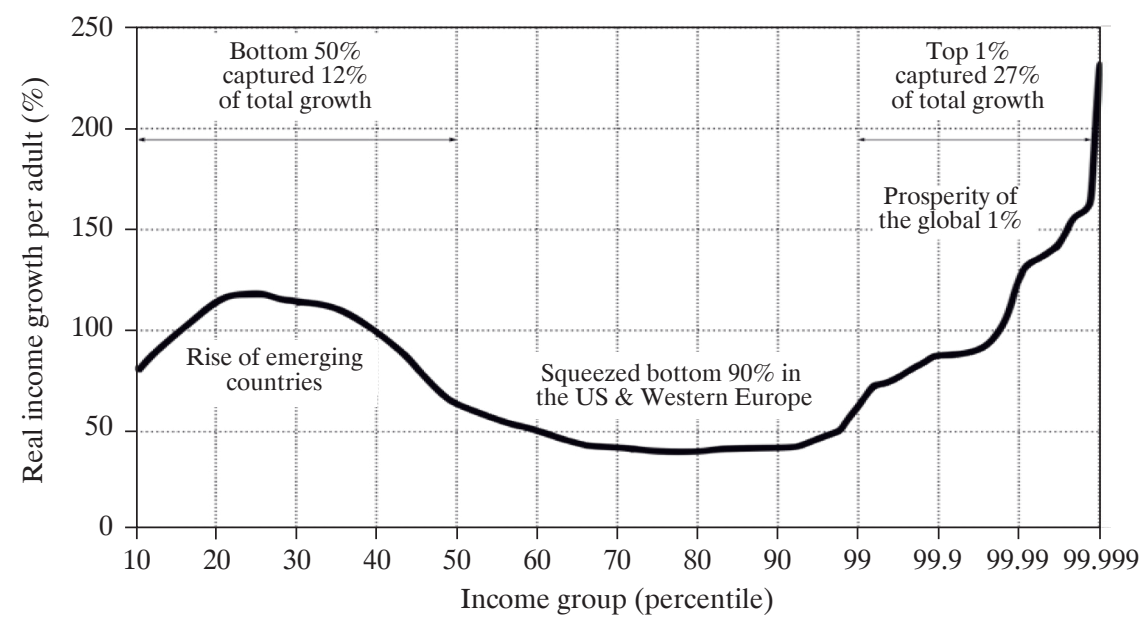

Fig. 3. Global Inequality and Growth 1980-2016

Source: World Inequality Report 2018 (2018, p. 13).

The graph can be explained as follows. On the horizontal axis, the world population is divided into a hundred groups of equal population size and sorted in ascending order from left to right, according to each group's income level. The top $1 \%$ group is divided into ten groups, the richest of these groups is also divided into ten groups, and the very top group is again divided into ten groups of equal population size. The vertical axis shows the total income growth of an average individual in each group between 1980 and 2016. For percentile group p99p99.1 (the poorest 10\% among the world's richest 1\%), growth was $74 \%$ between 1980 and 2016. The top $1 \%$ captured $27 \%$ of total growth over this period. Income estimates account for differences in the cost of living between countries. Values are net of inflation.

According to the WIR (2018, p. 9), inequality within world regions varies greatly. In 2016 the share of total national income accounted for by just the top $10 \%$ of earners (top 10\% income share) was $37 \%$ in Europe, $41 \%$ in China, $46 \%$ in Russia, $47 \%$ in US-Canada, and around $55 \%$ in Sub-Saharan Africa, Brazil, and India. In the Middle East, the world's most unequal region, the top $10 \%$ capture $61 \%$ of national income. The essential arguments for the conjectures linking socio-economic inequality with 
ideas deriving from complex systems studies (Power Law) are synthetically presented in the tables below.

Table 1. Global Income Growth ind Inequality, 1980-2016

\begin{tabular}{l|c|c|c|c|c|c}
\hline \multirow{2}{*}{ Income group } & \multicolumn{6}{|c}{ Total cumulative real growth per adult (\%) } \\
\cline { 2 - 7 } & China & Europe & India & Russia & $\begin{array}{c}\text { USA- } \\
\text { Canada }\end{array}$ & World \\
\hline Full population & 831 & 40 & 223 & 34 & 63 & 60 \\
\hline Bottom 50\% & 417 & 26 & 107 & -26 & 5 & 94 \\
\hline Middle 40\% & 785 & 34 & 112 & 5 & 44 & 43 \\
\hline Top 10\% & 1316 & 58 & 469 & 190 & 123 & 70 \\
\hline Top 1\% & 1920 & 72 & 857 & 686 & 206 & 101 \\
\hline Top 0.1\% & 2421 & 76 & 1295 & 2562 & 320 & 133 \\
\hline Top 0.01\% & 3112 & 87 & 2078 & 8239 & 452 & 185 \\
\hline Top 0.001\% & 3752 & 120 & 3083 & 25,269 & 629 & 235 \\
\hline
\end{tabular}

Source: World Inequality Report 2018 (2018, p. 45).

Table 2. Share of Global Growth (\%) Captured by Income Groups, 1980-2016

\begin{tabular}{l|c|c|c|c|c|c}
\hline Income group & China & Europe & India & Russia & $\begin{array}{c}\text { USA- } \\
\text { Canada }\end{array}$ & World \\
\hline Full population & 100 & 100 & 100 & 100 & 100 & 100 \\
\hline Bottom $50 \%$ & 13 & 14 & 11 & -24 & 2 & 12 \\
\hline Middle $40 \%$ & 43 & 38 & 23 & 7 & 32 & 31 \\
\hline Top $10 \%$ & 43 & 48 & 66 & 117 & 67 & 57 \\
\hline Top $1 \%$ & 15 & 18 & 28 & 69 & 35 & 27 \\
\hline Top $0.1 \%$ & 7 & 7 & 12 & 41 & 18 & 13 \\
\hline Top $0.01 \%$ & 4 & 3 & 5 & 20 & 9 & 7 \\
\hline Top $0.001 \%$ & 2 & 1 & 3 & 10 & 4 & 4 \\
\hline
\end{tabular}

Source: World Inequality Report 2018 (2018, p. 46).

Using the theoretical assumptions presented in the paper, a preliminary confirmation of the conjectures can be presented. First, in spite of doubts concerning the occurrence of the Power Law, its presence is partly proved in the wealth distribution and its dynamics in all the major regions of the world. Second, referring to various interpretations of social hierarchy, it may be emphasized that in highly developed societies in which material needs 
are fulfilled, the income and wealth hierarchy and inequalities occur in the symbolic sphere.

The classical hierarchies depicted earlier had significant physical features - levels of energy, potential, as well as the number, time, and frequency of interactions. In the Information Society hierarchies are becoming symbolic. This observation can also be supported by theories of money as a social construct (Barkin 2003). Consequently, inequality, both social and economic, is "played" in the symbolic sphere. In this case, all considerations about the dynamics of inequality, its consequences, and its future require not only more advanced data searches and econometric and / or ideological considerations but also comprehensive discussion based on studies of the complexity of social systems.

\section{Conclusions}

Theoretical concepts and factual illustrations allow us to put forward the following conclusions concerning the links between inequality on the global scale and a systems approach. First, complex systems studies provide additional evidence allowing for identification and a deeper understanding of the mechanisms leading to various types of inequality in social systems. The explanations are not sufficiently specific and unequivocal, but at the same time they are not too general, obvious, and intuitive. Second, the hierarchical structure of societies is a natural vehicle for differentiation in access to resources, both physical and intangible. This also concerns opportunities. It is not an ethical or ideological problem, but results from the "eigendynamik" of complex social systems.

Future research should include the broader application of interdisciplinary complex systems models in all areas of research on socio-economic inequality. This is almost self-evident, of course, but in practical terms it means that inter-disciplinarity should be the backbone of research. Two directions are of a special importance. First, studies of socio-economic inequality should be supported by theoretical considerations based on various ideas drawn from complex studies - hierarchical control systems, emergence, network theories, and simulation modelling. Second, these studies should include simulation models based on data already gathered by specialized research institutions. 


\section{Bibliography}

Alvaredo, F., Chancel, L., Piketty, T., Saez, E. and Zucman, G. (2017) “The Elephant Curve of Global Inequality and Growth”. WID.world Working Paper 20, https:// wid.world/document/elephant-curve-global-inequality-growth-wid-world-workingpaper-2017-20 (accessed: 23 May 2018).

Andriani, P. and McKelvey, B. (2009) "Perspective - From Gaussian to Paretian Thinking: Causes and Implications of Power Laws in Organizations". Organization Science 20(6), https://doi.org/10.1287/orsc.1090.0481.

Ashby, W. R. (1963) An Introduction to Cybernetics. New York: Wiley.

Barabási, A.-L. (2003) Linked. How Everything is Connected to Everything Else and What It Means for Business, Science, and Everyday Life. New York: Penguin.

Barabási, A.-L. and Albert, R. (1999) "Emergence of Scaling in Random Networks". Science 286(5439).

Barkin, S. J. (2003) Social Construction and the Logic of Money: Financial Predominance and International Economic Leadership. Albany, NY: State University of New York Press.

Bar-Yam, Y. (1997) Dynamics of Complex Systems. Reading, MA: Addison-Wesley.

Bertalanffy, L. von (1968) General Systems Theory. New York: Braziller.

Biggiero, L. (2001) "Sources of Complexity in Human Systems". Nonlinear Dynamics, Psychology and Life Sciences 5(1).

Bosch, H. van der (2017) "Own Country Second, World First! Redeeming The Losers Of Globalization”. Science for Society, April 15 th, https://hermanvandenbosch. com/2017/04/15/own-country-second-world-first (accessed: 17 April 2018).

Broido, A. D. and Clauset, A. (2018) Scale-free Networks Are Rare, https://arxiv.org/ abs/1801.03400 (accessed: 16 April 2018).

Brzeziński, M. (2013) Do Wealth Distributions Follow Power Laws? Evidence From "Rich Lists", https://arxiv.org/pdf/1304.0212.pdf (accessed: 14 January 2017).

Buchanan, M. (2002) Nexus: Small Worlds and the Groundbreaking Science of Networks. New York: W. W. Norton \& Company.

Carter, P. L. and Reardon, S. F. (2014) "Inequality Matters". A William T. Grant Foundation Inequality Paper, September, Stanford University, https://ed.stanford.edu/ sites/default/files/inequalitymatters.pdf (accessed: 21 January 2017).

Castellani, B. (2018) Brian Castellani on the Complexity Sciences, http://theory-culturesociety. org/brian-castellani-on-the-complexity-sciences (accessed: 20 February 2018).

Chatterjee, A., Ghosh, A., Inoue, J.-C. and Chakrabarti, B. K. (2015) "Social Inequality: From Data to Statistical Physics Modeling”. Journal of Physics. Conference Series 638.

Cilliers, P. (1998) Complexity and Postmodernism. London: Routledge.

Concepts of Inequality (2015) "United Nations Development Strategy and Policy Analysis Unit“. Development Issues 1, October 21st, http://www.un.org/en/development/desa/ policy/wess/wess_dev_issues/dsp_policy_01.pdf (accessed: 7 January 2017).

Dijk, J. A. G. M. van (2005) The Deepening Divide. Inequality in Information Society, Thousand Oaks: Sage Publications.

Freund, C. (2016) Deconstructing Branko Milanovic's “Elephant Chart”: Does It Show What Everyone Thinks?, Peterson Institute for International Economics (PIIE) November 30th, https://piie.com/blogs/realtime-economic-issues-watch/deconstructing-brankomilanovics-elephant-chart-does-it-show (accessed: 22 April 2018). 
Gleick, J. (1987) Chaos: The Making of a New Science. New York: Viking Press.

Holland, J. D. (1995) Hidden Order. How Adaptation Builds Complexity. New York: Basic Books.

Kauffman, S. A. (1995) At Home in the Universe. The Search for Laws of Self-organization and Complexity. New York/Oxford: Oxford University Press.

Koestler, A. (1967) The Ghost in the Machine. London: Penguin Group.

Krauss, A. (2015) "The Scientific Limits of Understanding the (Potential) Relationship between Complex Social Phenomena: The Case of Democracy and Inequality". Journal of Economic Methodology 23(1), https://doi.org/10.1080/1350178x. 2015.1069372.

Lakner, C. and Milanovic, B. (2013) "Global Income Distribution: From the Fall of the Berlin Wall to the Great Recession”. World Bank Policy Research Working Paper 6719.

Lakner, C. and Milanovic, B. (2015) "Global Income Distribution: From the Fall of the Berlin Wall to the Great Recession”. The World Bank Economic Review 30(2), https:// doi.org/10.1093/wber/lhv039.

Lakoff, G. and Johnson, M. (1995) Metaphors We Live by. Chicago: University of Chicago Press.

Lloyd, S. (2001) "Measures of Complexity: A Nonexhaustive List". IEEE Control Systems Magazine 21(4), https://doi.org/10.1109/MCS.2001.939938.

Luhmann, N. (1995) Social Systems. Palo Alto, CA: Stanford University Press.

Luhman, N. (1997) Die Gesellschaft der Gesellschaft. Frankfurt am Main: Suhrkamp.

Mesjasz, C. (2010) “Complexity of Social Systems". Acta Physica Polonica A 117(4), http:// przyrbwn.icm.edu.pl/APP/PDF/117/a117z468.pdf (accessed: 14 June 2018).

Milanovic, B. (2005) Worlds Apart: Measuring International and Global Inequality. Princeton, NJ: Princeton University Press.

Milanovic, B. (2016) Global Inequality. A New Approach for the Age of Globalization. Cambridge, MA: The Belknap Press of Harvard University Press.

Newman, M. E. J. (2006) Power Laws, Pareto Distributions and Zipf's law, https://arxiv.org/ pdf/cond-mat/0412004.pdf (accessed: 14 March 2015).

Piketty, T. (2014) Capital in the Twenty-first Century. Cambridge, MA: Harvard University Press.

Piketty, T. and Saez, E. (2014) "Inequality in the Long Run". Science 344(6186), https:// doi.org/10.1126/science.1251936.

Prigogine, I. and Stengers, I. (1984) Order Out of Chaos. New York: Bantam.

Sandefur, J. (2018) Chart of the Week \#1: Is the Elephant Graph Flattening Out?, Center for Global Development, January 4th, https://www.cgdev.org/blog/chart-week-1elephant-graph-flattening-out (accessed: 22 October 2018).

Sen, A. K. (1995) Inequality Re-examined. Oxford: Oxford University Press.

Sen, A. K. (1999) Development as Freedom. New York: Oxford University Press.

Shan, Y. and Yang, A. (2008) Applications of Complex Adaptive Systems. New York: IGI Publishing.

Simon, H. A. (1962) "The Architecture of Complexity". Proceedings of the American Philosophical Society 106(6).

Simon, H. A. (1995) Near Decomponsability and Complexity: How a Mind Resides in a Brain in J. H. Morowitz, J. L. Singer (eds) The Mind, The Brain And Complex Adaptive Systems [Santa Fe Institute Series]. Reading, MA: Addison-Wesley. 
Stanford Encyclopedia of Philosophy, http://plato.stanford.edu/contents.html (accessed: 7 January 2016).

Stiglitz, J. (2012) The Price of Inequality. How Today's Divided Society Endangers Our Future. New York: W. W. Norton \& Company.

Stiglitz, J. (2015) The Great Divide. Unequal Societies and What We Can Do About Them. New York: W. W. Norton \& Company.

"A Three-headed Hydra" (2014) Economist, July 16th, http://www.economist.com/blogs/ freeexchange/2014/07/measuring-inequality (accessed: 11 February 2017).

Turchin, P. and Gavrilets, S. (2009) "Evolution of Complex Hierarchical Societies". Social Evolution \& History 8(2), http://www.socionauki.ru/journal/articles/129288/ (accessed: 26 January 2017).

Waldrop, M. M. (1992) Complexity: The Emerging Science at the Edge of Order and Chaos. New York: Simon \& Schuster.

Warnecke, H. J. (1993) The Fractal Company. A Revolution in Corporate Culture. BerlinHeidelberg: Springer Verlag.

Weaver, W. (1948) "Science and Complexity". American Scientist 36(4).

Wiener, N. (1961) Cybernetics: Or Control and Communication in the Animal and the Machine. Paris-Cambridge, MA: Hermann \& CIE-MIT Press.

World Inequality Report 2018 (2018) World Inequality Lab, https://wir2018.wid.world/ (accessed: 23 May 2018).

Yakovenko, V. M. and Rosser, J. B. (2009) "Colloquium: Statistical Mechanics of Money, Wealth, and Income”. Reviews of Modern Physics 81(1703), https://doi.org/10.1103/ RevModPhys.81.1703.

\section{Abstract}

\section{Zastosowanie podejścia systemowego w badaniu globalnych nierówności spoleczno-ekonomicznych}

Koncepcje zaczerpnięte $\mathrm{z}$ podejścia systemowego, a w szczególności studia nad systemami złożonymi, były już wykorzystywane do opisu i wyjaśnienia przyczyn narastania nierówności na różnych poziomach hierarchii systemów społecznych, od jednostek po nierówności w skali globalnej. Biorąc pod uwagę wyniki badań nad nierównością społeczną i ekonomiczną, można zadać następujące pytanie: w jaki sposób podejście systemowe, obejmujące studia nad systemami złożonymi może być pomocne w badaniu nierówności społecznych i ekonomicznych w skali globalnej? Jako punkt wyjścia badań zostały przedstawione dwa przypuszczenia. Po pierwsze, nierówności społeczno-ekonomiczne w skali globalnej stanowią nieodłączną cechę współczesnego globalnego społeczeństwa i dotyczą regionów, krajów, grup społecznych i jednostek. Po drugie, podejście systemowe, w tym w szczególności badania systemów złożonych, mogą być wykorzystane w badaniu tych nierówności. Dotyczy to zwłaszcza wykorzystania systemów hierarchicznych oraz prawa potęgowego (prawa skalowania).

Słowa kluczowe: systemy złożone, nierówności, podejście systemowe, prawo potęgowe, sieci bezskalowe. 